\title{
AMOR DE VIUDA
}

\section{Juan Pedro APARICIO}

e había casado tres veces y las tres había enviudado. Le gustaban los hombres divertidos, S atrevidos, juerguistas. Pero cuando los tenía en casa la aburrían. Así, fue siendo más exigente con cada nuevo marido. Lo quería todavía más divertido, atrevido, juerguista. Y se casó una última vez, ahora con un hombre de notorio buen ánimo y mucho gracejo que, sin embargo, pronto comenzó a aburrirla también. Como ya era algo mayor, en sus ideas se le habían ido colando premoniciones de muerte y tenía pesadillas en las que se veía en el cielo escuchando su risa por toda la eternidad. Y ella en el cielo, eso lo tenía muy claro, quería ser libre. Un mal pensamiento que la llevó de cabeza al infierno. 